\title{
Grand challenges in agroecology and land use systems
}

\author{
P. K. Ramachandran Nair* \\ School of Forest Resources and Conservation, University of Florida, Gainesville, FL, USA \\ ${ }^{*}$ Correspondence: pknair@ufl.edu \\ Edited by: \\ B. Mohan Kumar, Indian Council of Agricultural Research, India \\ Reviewed by: \\ Eike Luedeling, World Agroforestry Centre, Kenya \\ María R. Mosquera-Losada, University of Santiago de Compostela, Spain \\ K. S. Rao, University of Delhi, India
}

Keywords: agroecology, agriculture, food production, agroecosystems, environmental sustainability, land degradation, biodiversity, land-use systems

Historically, agroecosystems the world over have responded rather resiliently to the increasing pressure for producing food for the expanding human population. Over the years, the two major strategies for producing more food were to increase the area under crops and to increase the production per unit area. The former was the main strategy until agriculture became commercialized, especially in industrialized nations, after World War II. With increasing understanding about the catastrophic consequences of clearing more area for agriculture (commonly referred to as deforestation), sheer lack of additional area to be brought under agriculture in some places, and rapid increase in human population, the emphasis shifted to ways of increasing production per unit area of land. The cornerstone of that strategy was the opportunities offered by the invention and/or introduction of the benefits of science and technology in agriculture by way of fertilizers and other agrochemicals, improved crop varieties capable of producing higher yields, and efficient manipulation of crop environment through management of resources such as soil and water. The Green Revolution, as it would become known, paid rich dividends during the latter part of the twentieth century in enhancing food production and averting large-scale hunger. During the second half of the century, for example, the global grain production tripled to about 2 billion tons ( $2 \mathrm{Pg})$, whereas the total global area under cultivation increased by only about $10 \%$, to 660 million ha. This remarkable achievement was brought about by the input of science and technology to agriculture (Borlaug and Dowswell, 2004).
Today, however, we face a two-pronged challenge on the food-production front: increasing the production at a much rapid rate than before to cope with the demands of the ever-increasing population, and to do that sustainably. The human population is expected to grow from the current 7 billion to an estimated 9 billion by 2050 (UNPD, 2010). The impact of this population increase on the food system is much more complex than a proportional increase in the demand for food. Today, nearly a billion people go hungry, while another billion over-consume and increase the risks from obesity-related diseases. Moreover, with incomes rising fast in emerging economies, diets shift toward higher consumption of calories, fats, and animal products; at least 3 billion people move up the food chain consuming more grain-intensive livestock and poultry products. These issues of who grows food and how and where it is grown have enormous bearing on the capacity of agroecosystems to produce the food sustainably. These sustainability issues are intricately related to the use-often misuse-of natural resources leading to their degradation and depletion, human migration to urban areas and across borders, and political and economic instability of nations.

The Green Revolution heralded the era of intensified agriculture characterized by increased (often excessive) use of agrochemicals and unsustainable levels of exploitation of natural resources to promote food and wood production. This led in many instances to serious degradation of ecosystems and disruption of ecosystem services the world over during the past few decades. It is not only intensified agriculture that causes these problems; non-scientific practices of subsistence farming such as the bush-fallow and other forms of shifting cultivation also have contributed to serious degradation of ecosystems (Nair, 2013). As global demand for food, fodder, and bioenergy crops grows, many agricultural systems are depleting soil fertility, reducing biodiversity, and impacting water resources (Beddington et al., 2011). Modern industrialized farming may look good only when the success is measured narrowly and the costly side-effects are ignored. It is often forgotten that agriculture affects the basis for its own future through land degradation, salinization, over-extraction of water, and the reduction of genetic diversity in crops and livestock. These effects have been most serious in developing countries where agricultural expansion has extended over areas that are ecologically unsuitable for crop production.

Thus, agroecosystem management is at crossroads today. We are under serious pressure to enhance the productivity of the system to cope with the increasing needs on the one hand, and maintain the sustainability of the production base on the other. The objective of this short paper is to examine the major environmental challenges facing the agroecosystems and discuss how agroecology principles could be applied to ecosystem management to ensure production of commodities while protecting the integrity and sustainability of the production base.

\section{GRAND CHALLENGES IN ENVIRONMENTAL SUSTAINABILITY GLOBAL HUNGER}

According to the 2013 report on the State of Food Insecurity in the World (SOFI, 
2013) released recently by the United Nations food agencies, some 842 million people, or roughly one in eight, suffered from chronic hunger in 2011-2013. Although the number is down from 868 million reported for the 2010-2012 period, it is still alarming. Food insecurity impacts communities throughout the world wherever poverty prevents assured access to food supplies; thus the vast majority of hungry people live in developing regions, while 15.7 million live in developed countries. Misuse and overexploitation of natural resources are other central factors underlying food gaps. Any technological policy for rural and agricultural development must be judged on not just the total global production of food, but several other factors including whether it tends to increase or decrease inequity in the distribution of and access to resources and food, and whether it ensures sustainability of resource use.

\section{CLIMATE CHANGE INDUCED BY HUMAN ACTIVITY}

Impact of human activities on the climate system is clear, according to the conclusion of the IPCC (Intergovernmental Panel on Climate Change) report of September 2013, which confirms that it is extremely likely (95-100\% probability) that most of the warming since 1950 has been due to human influence. The report notes that warming in the climate system is unequivocal and many changes that have been observed throughout the climate system are unprecedented over decades to millennia (www.ipcc.ch or www.climatechange2013.org). Tropical deforestation has long been listed as one of the major causes of $\mathrm{CO}_{2}$ emissions, and several reports are available on the extent of such emissions. A recent study by Baccini et al. (2012) estimated that tropical deforestation and resultant land use changes contributed about 1.0 $\mathrm{Pg} \mathrm{C} \mathrm{yr}^{-1}$ (about 15\% of total anthropogenic $\mathrm{CO}_{2}$ emissions) during 2000-2010 (Baccini et al., 2012). Current farming practices including land clearing and inefficient use of fertilizers and organic residues also make agriculture a significant contributor to greenhouse gas emissions on the planet. From the farm gate to consumers, transportation, refrigeration, and other supply chain activities are an additional major source of greenhouse gas emissions.

As in everything else, there are enormous inequalities among different countries and regions in energy consumption for agriculture as well. A good illustration of this point can be derived from the average annual grain consumptions in different countries and regions. For example, average grain consumption in the U.S., Italy, and India are approximately 800, 400, $200 \mathrm{~kg}$ per person (Brown, 2010). This may sound strange considering that Indian diet is predominantly vegetarian and therefore grain consumption might be expected to be higher there compared with other parts of the world. But, of the roughly $800 \mathrm{~kg}$ grain consumed per person each year in the U.S., only about $100 \mathrm{~kg}$ is eaten directly as bread, pasta, and breakfast cereals, while the bulk of the grain is used to feed the livestock and poultry to produce food products for human consumption, and is thus "consumed indirectly" by humans. By contrast, in India, where people consume just about $200 \mathrm{~kg}$ grain per year, nearly all grain is eaten directly to satisfy basic food energy needs; little is available for conversion into livestock products. The Mediterranean diet, on the other hand, includes a combination of meat, cheese, and seafood, but all in moderation, and is considered best for human health and longevity. The ramification of this high level of per capita grain consumption in the U.S. is the high energy cost of the food system and its inevitable impact on the environment.

\section{LAND DEGRADATION}

The underlying concept of land degradation as emphasized in various definitions is that it refers to the loss of actual or potential productivity and utility of land and decline in its quality. It implies decline in the land's inherent capacity to produce economic goods and perform functions of environmental moderation. The term is so broad-based that many problems of land management such as desertification, salinization, soil erosion, soil fertility decline, deforestation, biodiversity decline, and climate change are portrayed as various facets or indicators of land degradation. There is unanimity of views, however, that the consequences of land degradation are alarming: smaller harvests, reduced availability of clean water, increased vulnerability of the affected areas to climate change and, not least, food insecurity and poverty. The most widely used estimates are that about 2 billion hectares of land and 1.5 billion people are affected by one or more forms of land degradation, with the major share in developing countries (UNCCD, 2011; UNEP, 2013). An estimated 12 million hectares of agricultural land, which could potentially produce 20 million tons of grain, are now lost to land degradation every year, adding to the billions of hectares that are already degraded (Brown, 2007; Bai et al., 2008; UNEP, 2013). A rough calculation of current rates of soil degradation suggests we have about 60 years of topsoil left. Because of various farming methods that strip the soil of carbon and make it less robust as well as weaker in nutrients, soil is being lost at between 10 and 40 times the rate at which it can be naturally replenished (http://world.time.com/ 2012/12/14/what-if-the-worlds-soil-runsout/\#ixzz2M3vnF7KW).

\section{BIODIVERSITY DECLINE}

Biodiversity that refers to the diversity of life on Earth includes the richness (number), evenness (equity of relative abundance), and composition (types) of species, alleles, functional groups, or ecosystems (Isbell, 2012). The decline in biodiversity that is occurring rapidly worldwide may adversely affect functioning and stability of ecosystems (Naeem et al., 2009) and diminish human wellbeing by decreasing the services that ecosystems can provide for people (Millennium Ecosystem Assessment, 2005). A case in point is the serious challenge to global agriculture caused by decline of the honey bee, a major pollinator of many crops. The FAO has noted that 71 of the 100 crops that provide $90 \%$ of human food, with an estimated value of as much as $\$ 200$ billion annually are pollinated by bees (www.fao. org/ag/magazine/0512sp1.htm). In the United States, where honey bees are estimated to contribute over $\$ 17$ billion to the nation's economy (www.usda.gov/ documents/ReportHoneyBeeHealth.pdf), beekeepers have seen colony loss rates increase to 30 to $35 \%$ per year, as compared to historical loss rates of 10 to $15 \%$. 
The honey bee declines have been associated with a combination of many factors, including parasites, pests, pathogens, pesticides, and stress from colony transport (Woteki, 2013). The adverse impacts of land clearing (and habitat destruction) and increased use of agrochemicals in commercial agriculture on biodiversity decline have been widely discussed; however, concrete efforts based on scientific studies to address the problem are far too uncommon.

\section{WATER RESOURCES AND MANAGEMENT}

As the world's demand for water has tripled over the last half-century and as the demand for hydroelectric power has grown even faster, dams and diversions of river water have drained many rivers dry. Several countries are over-pumping aquifers as they struggle to satisfy their growing water needs, including each of the big three grain producers-China, India, and the U.S. More than half the world's people live in countries where water tables are falling. In India some 190 million people are being fed with grain produced by over-pumping groundwater; for China, there are 130 million in the same category (Brown, 2013). While falling water tables are largely hidden, rivers that are drained dry before they reach the sea are highly visible. Two rivers where this phenomenon can be seen are the Colorado, the major river in the southwestern United States, and the Yellow, the largest river in northern China. Other large rivers that either run dry or are close to it in the dry season are the Nile, the lifeline of Egypt; the Indus, which supplies most of Pakistan's irrigation water; and the Ganga (Ganges) in India's densely populated northern plains. Many smaller rivers have disappeared entirely.

Furthermore, growing populations, industrialization and agricultural practices lead to indiscriminate release of effluents to the land and water environment, resulting in severe pollution of water bodies both at the surface as well as in the subsurface environment.

\section{AGROECOLOGY AS AN APPROACH TO ADDRESSING THE GRAND CHALLENGES}

The environmental sustainability challenges to food production outlined above are indeed complex. They cannot be addressed by relatively "simple" solutions such as intensified agriculture using improved varieties and high amounts of chemicals that have produced substantial benefits in some parts of the world. Despite intense national and international efforts in applying such "straight-forward" solutions, sub-Saharan Africa and many other parts of the world lag behind in food production and other aspects of development. The Green Revolution technologies have proved to be unsuitable for Africa's infertile soils, unforgiving climate, weak infrastructure, and socio-cultural traditions. Technological solutions such as bioengineered varieties that are not locally adapted and must be purchased by cashstrapped farmers are not acceptable and their widespread introduction poses environmental risks and threats to genetic diversity of food crops and varieties. Thus, the environmental and human diversity of the planet forbids the imposition of onesize-fits-all solutions. As concluded by the Bellagio Report 2011 of the Commission on Sustainable Agriculture and Climate Change (Beddington et al., 2011), business as usual in our globally interconnected food system will not bring us food security and environmental sustainability. Several converging threats-from climate change, population growth and unsustainable use of resources-are steadily intensifying pressure on humanity and world governments to transform the way food is produced, distributed, and consumed.

The aphorism attributed to Albert Einstein that "the significant problems we face today cannot be solved by the same level of thinking we were at when we created them" is quite apt in this context. We need a different look at the problems and a different design of solutions. Agroecology is one of them. It entails a holistic approach to agriculture, based on the application of ecology to the design and management of sustainable agroecosystems, and aims at linking ecology, culture, economics, and society to sustain agricultural production and healthy environments (Altieri, 1995; Gliessman, 2000). Several authors, e.g., Altieri (1995) and Pretty (2008), have elaborated the advantages of such integrated approaches. As a path to sustaining agricultural productivity, integrated management relies on local farming knowledge and local conditions, management of diverse on-farm resources, and incorporation of contemporary scientific understanding of biological principles in farming systems. By relying on scientific management of local resources and knowledge in the most efficient manner, it offers a desirable and affordable way to restore agricultural lands that have been degraded by high-input agronomic practices and sustainably intensify production in marginal areas. Finally, by placing high emphasis on the "social capital" and value on local knowledge that peasant farmers already possess, agroecology has the potential to reverse the anti-peasant biases inherent in strategies of chemical agriculture. Thus, agroecology helps decrease rather than exacerbate the inequality and enhance ecological, social, and economic facets of sustainability.

\section{AGROFORESTRY AS AN EXAMPLE OF AN AGROECOLOGICAL APPROACH}

Time-tested practices such as agroforestry that rely on conservation farming and fertilizer trees to improve soil health and raise and sustain crop yields are a good example of large-scale application of the agroecology concept. During the past 30 years, research and development efforts have widely demonstrated the positive role of integrated agroforestry systems in addressing some of the major agroecosystem challenges outlined earlier such as food- and nutritional insecurity, soil degradation, desertification, and climate change (Nair and Garrity, 2012). Exploiting nitrogen fixation by tropical legume trees, enhancing the efficiency of nutrient cycling, and benefitting from the deep-capture of nutrients are recognized as the primary bases of the soil sustainability advantages of such systems. The focus of soil-improving qualities of multipurpose trees that dominated agroforestry research agenda during the 1980 and 1990s was on realizing these benefits at the farm or local level. Since the 1990s, other ecosystem services of trees that transcend from local to global levels such as climate change mitigation through carbon sequestration and biodiversity conservation have received increasing attention. The capture of atmospheric carbon dioxide in the aboveground biomass of trees and storage of carbon in their deep root systems are the premises for the perceived carbon 
sequestration benefits (Nair et al., 2010). The ability of vegetative buffer strips to reduce surface transport of agrochemical pollutants is the main premise of the water-quality issue, whereas the biodiversity conservation attributes of such systems stem from their species diversity and complexity. It has also become clear that intensified research has to go hand in hand with field application of its results in order to achieve long-term success in realizing the potential benefits.

These integrated land use systems and their social values have been ignored in our modern agricultural development efforts. We treat agriculture and forestry separately although these sectors are often interwoven on the landscape and share many common goals, and we have not given adequate attention to using modern scientific techniques for enhancing and exploiting the potential of indigenous plants that provide multiple products and ecosystem services and incorporating them into widely adoptable landuse systems. The time has arrived for a "re-marriage of trees and crops" and changing the rigid "either-or" stand on choosing between modern land-use technologies and conventional practices on the one hand, and eschewing the dichotomy between agriculture and forestry on the other. Business as usual is not an option, indeed.

\section{ACKNOWLEDGMENTS}

The author thanks Eike Luedeling and an anonymous reviewer for critical comments and valuable suggestions for improvement.

\section{REFERENCES}

Altieri, M. A. (1995). Agroecology: the Science of Sustainable Agriculture. Boulder, CO: Westview Press.
Baccini, A., Goetz, S. J., Walker, W. S., Laporte, N. T., Sun, M., Sulla-Menashe, D., et al. (2012). Estimated carbon dioxide emissions from tropical deforestation improved by carbon-density maps. Nature Clim. Change 2, 182-185. doi: 10.1038/ nclimate1354

Bai, Z. G., Dent, D. L., Olsson, L., and Schaepman, M. E. (2008). Global Assessment of Land Degradation and Improvement Identification by Remote Sensing. Wageningen: International Soil Reference and Information Centre (ISRIC).

Beddington, J., Asaduzzaman, M., Fernandez, A., Clark, M., Guillou, M., Jahn, M., et al. (2011). "Achieving food security in the face of climate change: summary for policy makers from the commission on sustainable agriculture and climate change," in CGIAR Research Program on Climate Change, Agriculture and Food Security (CCAFS), (Copenhagen). Available online at: www.ccafs. cgiar.org/commission

Borlaug, N. E., and Dowswell, C. R. (2004). "Prospects for world agriculture in the twenty-first century," in Sustainable Agriculture and the International Rice-Wheat System, eds R. Lal, P. E. Hobbs, N. Uphoff, and D. O. Hansen (New York, NY: Marcel Dekker), 1-18. doi: 10.1201/9780203026472.ch1

Brown, L. (2007). Losing soil. Washington, DC: The Earth Policy Institute. Available online at: www. earth-policy.org

Brown, L. (2010). Improving Food Security by Strategically Reducing Grain Demand. Washington, DC: The Earth Policy Institute. Available online at: www.earth-policy.org

Brown, L. (2013). Ten Things to Know About Food on World Food Day. Washington, DC: The Earth Policy Institute. Available online at: www. earth-policy.org

Gliessman, S. R. (2000). Agroecology: Ecological Processes in Sustainable Agriculture. Boca Raton, FL: CRC Press.

Isbell, F. (2012). Causes and consequences of biodiversity declines. Nat. Edu. Knowledge 3:54.

Millennium Ecosystem Assessment. (2005). Ecosystems and Human Well-Being: Synthesis. Washington, DC: Island Press.

Naeem, S., Bunker, D. E., Hector, A., Loreau, M., and Perrings, C. (eds.) (2009). Biodiversity, Ecosystem Functioning, and Human Wellbeing: An Ecological and Economic Perspective. Oxford: Oxford University Press. doi: 10.1093/acprof:oso/ 9780199547951.001.0001

Nair, P. K. R. (2013). Agroforestry: Trees in Support of Sustainable Agriculture. Encyclopedia of Earth Systems and Environmental Sciences. Elsevier.
Available online at: http://dx.doi.org/10.1016/ B978-0-12-409548-9.05088-0

Nair, P. K. R., and Garrity, D. P. (eds.). (2012). Agroforestry-The Future of Global Land Use. Netherlands, Dordrecht: Springer. doi: 10.1007/978-94-007-4676-3

Nair, P. K. R., Nair, V. D., Kumar, B. M., and Showalter, J. M. (2010). Carbon sequestration in agroforestry systems. Adv. Agron. 108, 237-307. doi: $10.1016 /$ S0065-2113(10)08005-3

Pretty, J. (2008). Agricultural sustainability: concepts, principles and evidence. Philos. Trans. R. Soc. Lond. B Biol. Sci. 363, 447-465. doi: 10.1098/rstb.2007.2163

SOFI (State of Food Security in the World). (2013). UN Food and Agriculture Organization (FAO), the International Fund for Agricultural Development (IFAD), and the World Food Programme (WFP). Available online at: www.fao.org

UNCCD (United Nations Convention to Combat Desertification). (2011). Desertification: a Visual Synthesis. Bonn: UNCCD Secretariat. Available online at: www.unccd.int/knowledge/docs/ Desertification-EN.pdfs

UNEP (United Nations Environment Programme). (2013). UNEP Annual Report 2012. Available online at: http://www.unep.org/annualreport/ 2012/

UNPD (United Nations Population Division). (2010). World Population Prospects: the 2010 Revision. New York, NY: UN Department of Economic and Social AffairsUN Population Division. Available online at: http:// esa.un.org/wpp/unpp/panel_population.htm

Woteki, C. (2013). The road to pollinator health. Editor. Sci. 341, 695. doi: 10.1126/science.1244271

Received: 31 October 2013; accepted: 06 January 2014; published online: 28 January 2014.

Citation: Nair PKR (2014) Grand challenges in agroecology and land use systems. Front. Environ. Sci. 2:1 doi: 10.3389/fenvs.2014.00001

This article was submitted to Agroecology and Land Use Systems, a section of the journal Frontiers in Environmental Science.

Copyright $\odot 2014$ Nair. This is an open-access article distributed under the terms of the Creative Commons Attribution License (CC BY). The use, distribution or reproduction in other forums is permitted, provided the original author(s) or licensor are credited and that the original publication in this journal is cited, in accordance with accepted academic practice. No use, distribution or reproduction is permitted which does not comply with these terms. 